Proceedings

\title{
A Novel Hydrogel of Poloxamer 407-Chitosan-hyaluronic Acid as Possible Wound Healing in Skin and Mucosa ${ }^{\dagger}$
}

\author{
José L. Soriano-Ruiz ${ }^{1, *}$, Noelia Pérez-González ${ }^{1}$, Nuria Bozal-de Febrer ${ }^{2}$, María Rincón ${ }^{3}$, Beatriz Clares ${ }^{1, *}$ \\ and Ana C. Calpena ${ }^{3}$
}

Citation: Soriano-Ruiz, J.L..;

Pérez-González, N.; Bozal-de Febrer,

N.; Rincón, M.; Clares, B.; Calpena,

A.C. A Novel Hydrogel ofPoloxamer 407-chitosan-hyaluronic Acid as Possible Wound Healing in Skin andMucosa. Proceedings 2021, 78, 53. https://doi.org/10.3390/ IECP2020-09108

Published: 11 January 202

Publisher's Note: MDPI stays neutral with regard to jurisdictional claims in published maps and institutional affiliations.

Copyright: (c) 2021 by the authors. Licensee MDPI, Basel, Switzerland. This article is an open access article distributed under the terms and conditions of the Creative Commons Attribution (CC BY) license (http://creativecommons.org/licenses /by/4.0/).
1 Department of Pharmacy and Pharmaceutical Technology, Faculty of Pharmacy, University of Granada, 18071 Granada, Spain; noelia.perez@correo.ugr.es

2 Department of Biology, Healthcare and the Environment, Faculty of Pharmacy and Food Sciences, University of Barcelona, 08028 Barcelona, Spain; nuria.bozal@ub.edu

3 Department of Pharmacy, Pharmaceutical Technology and Physical-chemistry, Faculty of Pharmacy and Food Sciences, University of Barcelona, 08028 Barcelona, Spain; maria.rincon@ub.edu (M.R.); ana.calpena@ub.edu (A.C.C.)

* Correspondence: jlsoriano@correo.ugr.es (J.L.S.-R.); beatrizclares@ugr.es (B.C.)

† Presented at the 1st International Electronic Conference on Pharmaceutics, 1-15 December 2020; Available online: https://iecp2020.sciforum.net/.

\section{Background}

The use of hydrogels in the treatment of wound healing is becoming an increasingly routine. Hydrogels are materials that protect wound healing, avoiding and/or controlling infection and providing moisture for the irregular wound environment. Poloxamer 407 (P407), chitosan (CH) and hyaluronic acid (HA) are biomaterials investigated to promote wound repair. P407 has thermoreversible properties and promotes wound contraction [1]. $\mathrm{CH}$ presents inherent analgesic, hemostatic and microbial effects [2]. HA interacts directly with cells through its cell surface receptors resulting in fibroblast proliferation and protein synthesis [3].

\section{Purpose}

The aim of this work was to develop and characterize a hydrogel (HG) prepared from a physical mixture of $\mathrm{P} 407, \mathrm{CH}$ and $\mathrm{AH}$ for the treatment of skin and mucosal wounds.

\section{Methods}

The $0.5 \%$ CTS was dispersed in $0.5 \%$ acetic acid. Previously prepared $0.2 \%$ HA solution was added to the previous solution. The final HG was made by adding P407 (18\%) using the cold method with continuous stirring for $24 \mathrm{~h}$. The HG was characterized by the following methods: swelling test, microbiological and in vivo studies. Swelling rate was assessed by a gravimetric method in phosphate buffer saline (PBS) at $32 \pm 0.5^{\circ} \mathrm{C}$ for $\mathrm{pH} 5.5$ and $37 \pm 0.5^{\circ} \mathrm{C}$ for $\mathrm{pH}$ 7.4. The antimicrobial activity was evaluated through a Kirby-Bauer Disk Diffusion Susceptibility Test [4] against Gram-negative bacteria, Gram-positive bacteria and fungi. The wound healing efficacy of the HG was evaluated in burn inducted mice. The formulation was applied topically once a day over14 days. Two groups were evaluated: hydrogel and reference formulation.

\section{Results and Discussion}

The swelling behavior in wound healing could help to absorb exudates and provides mechanical resiliency to the delivery system at the biological site of action [4]. Our results showed high swelling rates, the best value being at $\mathrm{pH}=5.5$. The HG provides an 
important improvement on antimicrobial properties and showed similar activity to reference. The wound healing in animals treated with HG was similar to Silvederma ${ }^{\circledR}$.

\section{Conclusions}

The HG exhibited important antimicrobial and biological effects.Thus, this hydrogel could be proposed as a suitable vehicle for new therapies for wound healing and infections on skin and mucosa.

Funding: This research received no external funding.

Institutional Review Board Statement: The study was conducted according to the guidelines of the Declaration of Helsinki, and approved by the Ethics Committee of the University of Barcelona (IRB00003099).

Informed Consent Statement: Not applicable.

Conflicts of Interest: The authors declare no conflict of interest.

\section{References}

1. Leyva-Gómez, V. Population statistics by Mexican federal entity. Mater. Sci. Eng. C 2017, 74, 36-46.

2. Zhao, X.; $\mathrm{Wu}, \mathrm{H} . ; \mathrm{Guo}, \mathrm{B}$; Dong, R.; Qiu, Y.; Ma, P.X.Antibacterial anti-oxidant electroactive injectable hydrogel as self-healing wound dressing with hemostasis and adhesiveness for cutaneous wound healing. Biomaterials 2017, 122, 34-47.

3. Zhao, X.; Wu, H.; Guo, B.; Dong, R.; Qiu, Y.; Ma, P.X.Antibacterial anti-oxidant electroactive injectable hydrogel as self-healing wound dressing with hemostasis and adhesiveness for cutaneous wound healing. J. Appl. Biomater. Funct. Mater. 2016, 14, e9-e18.

4. Gao, Y.; Kong, W.; Li, B.; Ni, Y.; Yuan, T.; Guo, L.;Lin, H.; Fan, H.; Fan, Y.; Zhang, X. Fabrication and characterization of collagen-based injectable and self-crosslinkable hydrogels for cell encapsulation. Colloids Surf. B Biointerfaces 2018, 167, 448-456. 